\title{
Maamme asuntotilasto ja sen kehittäminen
}

\section{Kirjoittanut Aarno Strömmer.}

Asuntopolitiikkamme tärkeimpiä lähiajan tavoitteita lienee ns. asuntopoliittisen kokonaisohjelman luominen. Tehtävä edellyttää perinpohjaista asiaan paneutumista ja samalla yksityiskohtaista ja luotettavaa tilastoa. Tämän kirjoituksen tarkoituksena on luoda valaistusta kysymyksiin, millaisia tietoja virallinen tilasto tarjoaa asuntopoliittiselle suunnittelulle, miten niiden kokoaminen ja julkaiseminen on järjestetty, ja myös lyhyesti, miten asuntotilastoa olisi pyrittävä edelleen kehittämään.

Asuntotilastolla tarkoitetaan tavallisesti vain ns, asuntolaskentoja, asunto-olojen selvityksiä. Tässä yhteydessä tarkastelu ulotetaan kuitenkin laajemmalle, niin että myös asunnontuotannon, rakennustoiminnan kustannusten ja rahoituksen sekä asunnontarpeen ja asumiskustannusten vaihteluita esittävät tilastonhaarat tulevat mukaan. Kirjoitus voidaan kuin luonnostaan jakaa kahteen osaan, deskriptiiviseen asuntotilaston historian ja nykyisen järjestelyn esitykseen sekä sen edelleen kehittämisen selvittelyyn.

\section{Asuntotilaston tähänastinen kehitys ja nykyinen järjestely.}

Asuntolaskennat ja asunto-olojen tutkimukset.

Väestökeskukset. Voimakas kaupunkeihin muutto 1800luvun jälkipuoliskolla aiheutti sen, että väestökirjanpito ja sen mukana väkilukutilasto alkoi yhä enemmän poiketa todellisuudesta. Asiantilan korjaamiseksi tilastollinen päätoimisto rupesi 
vuodesta 1870 lähtien suorittamaan suurimmissa väestökeskuksissa joka kymmenes vuosi henkilökohtaiseen kyselyyn perustuvia väestölaskentoja, joihin liitettiin myös asunto-olojen tiedustelu. ${ }^{1}$ Näissä vuosien $1870-1930$ ki in teist ö- ja a suntolaskennoiss a tutkittujen paikkakuntien luku nousi laskennasta toiseen. Kysymysten piiri luonnollisesti myös vaihteli yleensä kuitenkin laajentuen aikaisempiin tiedusteluihin verrattuna. Vuonna 1930 saatiin kiinteistöistä ja rakennuksista sekä varsinaisista asumisoloista kuten asuntojen mukavuuksista, asumistiheydestä ja ahtaasti asumisesta, vuokrista, alivuokralaisista ja asukeista jo varsin monipuolinen aineisto. Kaupunkilaskentojen käytäntöä seuraten määrättiin vuonna $1938 \mathrm{kok}$ o $\mathrm{m}$ a a t a koskeva kiinteistö- ja asuntolaskenta suoritettavaksi joka kymmenes vuosi toimeenpantavan y le is en väestöl a skennan yhteydessä. Vuodesta 1950 alkava koko maan käsittävien laskentojen sarja (ks. ss. 11-12) tulee siten tavallaan olemaan jatkona edellä mainituille vain suurimpiin väestökeskuksiin rajoittuneille asuntotiedusteluille.

Viralliseen tilastoon sisältyy myös kaksi sosiaaliministeriön sosiaalisen tutkimustoimiston suorittamaa väestökeskusten asuntoolojen selvitystä. V u on n a 1919 toimeenpantiin kaikissa kaupungeissa ja kauppaloissa sekä lisäksi 65:ssä johonkin maalaiskuntaan kuuluvassa taajamassa asuntolaskenta, jonka tehtävänä oli luoda pohja vuoden 1918 asuntokomitean työlle. ${ }^{2}$ Tässä laskennassa selviteltiin lähinnä asuntopulan erilaisia ilmenemismuotoja, kuten asuntovarannon suuruutta, asumistiheyttä ja asukkijärjestelmää. Vuonna 1937 asetetun kaupunkien asuntokomitean pyynnöstä sosiaalinen tutkimustoimisto suoritti uuden asunto-olojen selvityksen vuonna $1938 .^{3}$ Alueeltaan se oli edellistä rajoitetumpi, siinä tutkittiin näet vain 9 "edustavaksi", katsottua kaupunkia. Lisäksi selvitys kohdistui ainoastaan pienasuntoihin, ts. enintään 3 huonetta käsittäviin huoneistoihin. Tiedustelukohteiden lukua rajoitettiin vielä siten, että näistä pienasunnoistakin tutkittiin vain osa. Kun aineistoa voitiin näin supistaa, kävi myös mahdolliseksi lisätä selvitettävien yksityis- 
kohtien määrää. Niinpä tutkittiin mm. sellaiset aikaisemmin valaisematta jääneet seikat kuin asuntojen kunto, rakentamisen ajankohta, huoneistojen pinta-ala, huoneiden korkeus, lapsiperheiden asunto-olot ja huoneiden käyttö makuuhuoneina. Vuokrien suuruutta oli selvitetty jo kymmenvuotislaskennoissa, mutta niiden vertaamista asukkaiden tuloihin - kuten nyt tehtiin - ei ollut aikaisemmin suoritettu. Uutta oli niinikään eri yhteiskuntaryhmien asunto-olojen vertailu.

Paitsi varsinaisissa laskennoissa on väestökeskusten asuntooloja valaistu myös niissä eri väestöryhmien olojen selvityksissä, jotka on julkaistu virallisen tilaston työtilaston sarjassa ennen ensimmäistä maailmansotaa ja sosiaalisissa erikoistutkimuksissa sen jälkeen. Samanlaisia selvityksiä on lisäksi ilmestynyt Sosiaalisessa Aikakauskirjassa. Yksinomaan asunto-oloja koskevina ovat huomattavat sosiaalisen tutkimustoimiston suorittamat tiedustelut tehdastyövä en asuntooloista vuonna 1925 ja y lioppilaiden asunto-oloista syyslukukaudella $1949 .^{4}$

Virallisen tilaston ohella on syytä mainita että myös kunnat ovat alueellaan toimituttaneet asuntolaskentoja. Oman ryhmänsä näistä muodostavat ns. vähävaraisten as unto-olojen t u tkim ukset 1900-luvun alussa." Omaa luokkaansa kunnallisten asuntolaskentojen joukossa taas ovat kanslianeuvos $G$. Modeenin vuosina 1935-36 suorittamat Kotkan ja Varkauden selvitykset. ${ }^{6}$ Niiden kohteena eivät olleet vain työväestön, vaan kunnan koko väestön asunto-olot. Omaperäistä, muualla julkaisematonta tilastoa sisältyy myös eräisiin yksityisiin - mm. prof. Heikki Wariksen ja dos. Armas Niemisen Helsinkiä koskeviin ${ }^{\top}$ - tutkimuksiin.

Ma a s utu. Varhaisin maaseudun asuntoja koskeva numeroaines sisältyy virallisen tilaston katsauksiin Suomen taloudelliseen tilaan viisivuotiskausina 1876-1895. Tiedot olivat kuitenkin niin epäluotettavat, ettei niitä enää vuodelta 1900 katsottu voitavan edes julkaista. Ensimmäinen varsinainen asuntolaskenta 
maaseudulla on prof. Hannes Gebhardin vuonna 1901 tilattoman väestön alakomitean toimeksiannosta suorittama tiedustelu, joka liittyi osana laajempaan yhteiskuntataloudelliseen tutkimukseen. ${ }^{8}$ Se käsitti maamme kaikki maalaiskunnat ja myös niiden koko väestön. Tiedustelussa keskeisen asuntojen hallintamuodon lisäksi selvitettiin niiden huoneluku, asumistiheys sekä asunnottomien eli »loisruokakuntien» määrä. - Tämän samoin kuin eräiden muidenkin maaseudun selvitysten tuloksia esitellään lähemmin toisessa, maaseudun asuntokysymystä käsittelevässä kirjoituksessa.

Seuraavat kaksi virallista maaseudun asuntotutkimusta koskivat ainoastaan maataloustyöväkeä, ja ne suoritti sosiaalinen tutkimustoimisto. Niissä selvitettiin lähinnä asunnon omistussuhteita, sen suuruutta ja asumistiheyttä. Edellinen palkkausvuonna 1919-1920 suoritettu - käsitti 4779 asuntoa 49:stä edustavaksi katsotusta kunnasta. Jälkimmäinen suoritettiin vuonna 1927, ja se käsitti 4292 asuntoa 61 kunnasta.?

Samanaikaisesti kaupunkien asuntokomitean kanssa vuonna 1937 asetettiin komitea pohtimaan maaseudun asunto-olojen parantamista. Kiireellisimpään tarpeeseensa se toimeenpani saman vuoden huhti-toukokuussa ns. alustavan asuntotutkimuksen, johon sisältyi 2525 asuntoa 25 kunnasta. ${ }^{10}$ Yksityiskohtaisempaa selvitystä suorittamaan komitean yhteyteen perustettiin väliaikainen tutkimustoimisto, jonka työtä johti kanslianeuvos G. Modeen. Sen laatima tutkimus maseudun asunto-oloista vu onna 1937 kohdistui kaikkiin asuntoihin 56 maaseutukunnassa, jotka oli valittu tasaisesti eri puolilta maata. ${ }^{11}$ Sisällöltään tutkimus vastasi edellä selostettua vuoden $1938^{\circ}$ kaupunkitutkimusta, joten se oli aikaisempia maaseudun selvityksiä huomattavasti perusteellisempi.

Yleisen väestölaskennan yhteydessä vuoden 1950 lopussa suoritettu kiinteistö- ja asuntotiedustelu ulottui luonnollisesti myös maalaiskuntiin. Helmikuussa samana vuonna asetettu $\mathrm{m}$ a a s e udun asunto-olojen parantamiskomitea ei kuitenkaan voinut jäädä odottamaan sen tuloksia, vaan toimeenpani 
oman tutkimuksensa kunnanhallitusten välityksellä. Erikoista oli, että tietojen hankkimistapa jätettiin kunnanhallitusten harkintaan. Yleensä tietojen keräys tapahtui niin, että paikkakuntaa tuntevilta henkilöiltä koottiin alkutiedot, joista kuntayhdistelmä sitten laadittiin. Tilastot sisältävät lääneittäiset tiedot asuntojen kokonaismäärästä, niiden kunnosta, asuntovajauksesta, ahtaasti asumisesta sekä eräistä komitean työlle tärkeistä seikoista, kuten uusimistarpeessa olevien asuntojen hallintasuhteesta. ${ }^{12}$

Edellä selostettujen virallisten, so. valtionkomiteoiden ja sosiaalisen tutkimustoimiston selvitysten lisäksi on samoin kuin väestökeskustenkin kohdalla mainittava, että omaperäistä tilastoa sisältyy myös yksityisten tutkijoiden - mm. prof. Severi Savosen, agr. Erkki J. Kinnusen, prof. Antti Mäen ja dos. Armas Niemisen $^{13}$ - suorittamiin tutkimuksiin.

Asuntolaskentojen nykyinen järjestely. Edellä esitettyyn katsaukseen on ofettu mukaan - jonkinlaisen bibliografian laatimiseksi - sellaisetkin asunto-olojen tutkimukset, jotka eivät ole varsinaisia asuntolaskentoja. Niitähän lienevät ainoastaan kymmenvuotislaskennat suurimmissa kaupungeissamme 1870 - 1930, väestökeskusten tutkimukset vuosina 1919 ja 1938 sekä maaseudun tutkimukset 1901 ja 1937. Säännölliset kymmenvuotislaskennat on toimeenpannut tilastollinen päätoimisto, kun taas muut on suoritettu jonkin asuntokysymystä pohtivan komitean välitöntä tarvetta tyydyttämään. Aikaisempia asunto-olojen selvityksiä tarkasteltaessa on näin ollen varsin luonnollisena havaintona laskentojen jatkuvuuden ja yhtenäisyyden puute. Erityisesti tämä havainto koskee maaseutua. Prof. Leo Harmaja totesikin vuonna 1939 julkaisemassaan Tilastotieteen oppikirjassa, että »meillä on ehditty koota tilastotietoja esim. siitä, millainen lattia sikaloissa on, mutta ei ole katsottu mahdolliseksi jatkuvan tilaston aikaansaantia siitä, millaisissa asunnoissa maalaisväestö meillä elää». ${ }^{14}$

Kuten jo aikaisemmin mainittiin, asuntolaskentojen suhteen on kuitenkin päästy lakisääteiseen järjestelyyn, jonka mukaan 
koko asuntokannan käsittävä kiinteistö- ja asuntolaskenta suoritetaan kaikissa maamme kunnissa joka kymmenes vuosi yleisen väestölaskennan y hteydessä. ${ }^{1.5}$ Laskennan toimittaa tilastollinen päätoimisto, joka myös vahvisiaa kyselylomakkeєt ja päättää, mitä seikkoja tiedustelussa tullaan selvittämään. Näin lask€ntojen jatkuvuuden ohella on luatu edellytykset sekä alueeltaan että sisällöltään yhtenäisen tilaston luomiselle. Tämän »uuden sarjan» ensimmäisen laskennan aineisto on parhaillaan (1953) käyttelyn alaisena tilastollisessa päätoimistossa. ${ }^{16}$

\section{Muи asuntotilasto.}

$\mathrm{V}$ a lmistuneet as un not. Niiden toimenpiteiden pohjaksi, joihin valtio ryhtyi asuntopulan poistamiseksi ensimmäisen maailmansodan jälkeen, sosiaaliministeriö kokosi vuosina 1922$1923 \mathrm{k}$ a u punkien maistraateilta uudisrakennusten tarkastuksissa kertyneet tiedot vuosien 1912-22 aikana asuttavaan kuntoon valmistuneista huoneistoista. Sarjaa täydennettiin vuonna 1926 kolmen edellisen vuoden osalta, minkä jälkeen sitä on julkaistu vuosittain Sosiaalisessa Aikakauskirjassa. ${ }^{17}$ Vuodesta 1936 alkaen tilasto on sisältänyt myös k a u p a l a t. Määrätyt tiedot suurimmista väestökeskuksista on julkaistu neljännesvuosittain vuodesta 1941 lähtien. Tilaston kokoaa sosiaalinen tutkimustoimisto. Siihen palataan vielä tuonnempana asuntotilaston kehittämistä pohdittaessa.

Tiedot $\mathrm{m}$ a a s e u d u 11 a valmistuneista asunnoista ovat varsin vähäiset. Vuoden 1952 alussa kulkulaitcsten ja yleisten töiden ministeriöön perustettu rakennustoiminnan säännc̈istelyelin, rakennusasiain toimikunta, kerää vuosineljänneksittäin tietoja paitsi myönnetyistä rakennusluvista ja keskeneräisistä rakennuksista myös valmistuneista »huonerakennustöistä». Tämä kaikista kunnista koottava aineisto sisältää lähinnä erityyppisten rakennusten lukumäärän ja kokonaistilavuuden, mutta sìtä saadaan myös asuinhuoneistojen kokonaisluku. Valmistuneita asuntoja koske- 
vat väéstökeskusten luvut tarkoittavat lopputarkastuksessa hyväksyttyjä asuntoja, kun taas sosiaalisen tutkimustoimiston tiedot koskevat asuttavaan kuntoon valmistuneita eli jo väliaikaisen tarkastuksen jälkeen käyttöön luovutettuja asuntoja. Rakennusasiain toimikunta kokoaa tilastoaan ensi sijassa omaan käyttöönsä, tiettyyn hallinnolliseen erikoistarkoitukseen. Ainakin toistaiseksi täten saadut tiedot on saatettu julkisuuteen vain rakennussäännöstelyä koskevien kirjoitusten ja sanomalehtiuutisten välityksellä.

Myönnetyt rakennusluvat. Rakennusasiain toimikunta kerää tilastoa myönnetyistä rakennusluvista vuosineljänneksittäin. Vuosittaisia tietoja on kuitenkin jo pitemmältä ajalta. Sosiaalinen tutkimustoimisto on nimittäin koonnut rakennuslupatilastoa kaupungeista vuodesta 1931, kauppaloista vuodesta 1932 ja m a a s e u d u l t a vuodesta 1949 lähtien. ${ }^{18}$ Väestökeskusten luvut julkaistaan samoissa katsauksissa kuin tiedot valmistuneista asuinhuoneistoista, kun taas maaseudun aineisto julkaistaan omana selvityksenään Sosiaalisessa Aikakauskirjassa. Väestökeskuksista saadaan paitsi asuntojen ja huoneiden kokonaismäärää myös tietoja erilaisten rakennusten yhteistilavuudesta ja -pinta-alasta. Maaseudun aineisto kootaan huomattavasti täydellisempänä, koska varsinaista tuotantotilastoa ei sieltä ole voitu laatia. Syyksi viimeksi mainittuun seikkaan on mainittu, että laki ei maaseudulla velvoita rakennusviranomaisia suorittamaan lopputarkastusta. Tilastossa on asuinhuoneistot ryhmitelty huoneluvun mukaan, erilaisista rakennuksista saadaan lukumäärä ja yhteistilavuus, ja viimeksi mainittu on ryhmitelty edelleen rakennuttajan mukaan.

Rakennuskustannukset. Asunnontuotannon kustannusten kehitystä kuvaa Suomen Pankin rakennuskustannusindeksi, joka julkaistiin ensimmäisen kerran vuonna 1942. Sen jälkeen tilastoa sen kehityksestä on ilmestynyt säännöllisesti mm. Sosiaalisessa Aikakauskirjassa. Kaudelta 1922 -1938 indeksi on laskettu vuosittain ja kaudelta $1939-1951$ neljännesvuosittain. Kyseisten sarjojen perusvuotena oli 1935 . Ny- 
kyisin laskettavan indeksin basis on 1951, mistä lähtien se on julkaistu kuukausittain. Uusitun indeksin painotusjärjestelmän pohjana on viisi vuosina 1948 -1950 rakennettua kantavaseinäistä hissitöntä asuintaloa. Indeksin hintatiedot kerätään jatkuvasti Helsingistä. Kokonaisindeksin lisäksi lasketaan myös eri kustannustekijöiden kehitystä valaisevat sarjat. ${ }^{19}$

Rakennustoiminnan rahoitus. Nykyisen asuntopolitiikkamme keskeisin työmuoto on epäilemättä asunnontuotannon tukeminen valtion varoista myönnettävin lainoin ja avustuksin. Niitä koskevat tilastotiedot saadaan lainoitustoiminnasta huolehtivien viranomaisten kertomuksista. Sosiaaliministeriön asuntoasiaintoimiston selonteot »valtion tukemasta yleishyödyllisestä asunnonrakennustoiminnasta» väestökeskuksissa vuosina $1941-1948$ ja vuoden 1949 ensimmäisellä neljänneksellä on julkaistu Sosiaalisessa Aikakauskirjassa. Lainojen myöntämisen siirryttyä A r a v a 11 e huhtikuun 1949 alusta tiedot on julkaistu edelleen samassa aikakauskirjassa mainitun viraston toimesta. Paitsi lainoitettujen asuintalojen rahoitusta, kustannuksia ja rakennuttajia selvitetään myös asuntojen lukumäärä, pinta-ala ja huoneluku. Niinikään katsauksiin sisältyy lukuja perheenasuntoavustuksista, joita on myönnetty vuodesta 1942 lähtien.

Maaseudun asunnontuotannon tukeminen julkisista varoista on alunperin kytkeytynyt asutustoimintaan. Sitä koskeva numeroaineisto on sen vuoksi ilmestynyt virallisen tilaston asutustilaston sarjassa (SVT XXX). Ma a tausministeriön asut us a sia in os a st o on lisäksi vuodesta 1948 lähtien julkaissut Asutustoiminnan Aikakauskirjaa, johon sisältyy asutuslainsäädännön - mm. maanhankintalain - mukaista lainoitusta sekä maaseudun asunto-olojen parantamiseen myönnettyjä avustuksia, lainoja ja palkkioita koskevaa tilastoa.

As unnontarve. Useat tutkijat ovat laatineet väestö- ja asuntotilastoon perustuvia laskelmia asunnontarpeen kehityksestä ja asuntopulan laajuudesta. ${ }^{20}$ Eräänlainen jatkuva asunnon- 
tarvitsijatilasto on Sasiaalisessa Aikakauskirjassa vuosineljänneksittäin julkaistu kaupunkeja, kauppaloita ja Espoon kuntaa koskeva tilasto huoneenvuokralautakuntien asunnonvälityskortistoon otetuista asunnonhakij o ista. Sosiaalinen tutkimustoimisto on kerännyt tätä aineistoa säännöllisesti syyskuusta 1944 lähtien. Paitsi hakijatalouksien kokonaismäärää siitä saadaan tietoja $\mathrm{mm}$. asunnontarpeen syistä sekä siitä, moniko talouksista on päävuokralainen, alivuokralainen tai asuu matkustajakodeissa tms. Vuodesta 1948 alkaen on sosiaaliministeriön asuntoasiaintoimisto lisäksi hankkinut tiedot niistä hakijoista, joiden asunnontarve vaatii kiireellisiä toimenpiteitä.

Asumiskustannukset. Useiden asuntotiedustelujen, mm. vuosien 1900, 1910 ja 1930 kaupunkilaskentojen sekä vuosien 1937-1938 tutkimusten yhteydessä on koottu asumiskustannuksia, so. vuokria koskevia tietoja. Asuinhuoneistojen keskimääräisen kuukausivuakran suuruutta ja kehitystä eri väestökeskuksissa valaisevat ne vuokralaskennat, joita sosiaalinen tutkimustoimisto on suorittanut elinkustannusindeksin ja paikkakuntien kalleusryhmityksen tarpeisiin vuodesta 1924 lähtien. Tulokset on julkaistu Sosiaalisessa Aikakauskirjassa. Vuoteen 1941 saakka tiedot on edustavaa menetelmää käyttäen koottu säännöllisesti joka vuosi. Viime sodan jälkeen on suoritettu kolme vuokratiedustelua. Marraskuussa 1946 toimeenpantiin tiedustelu vuosina 1942-1946 kaupungeissa ja kauppaloissa valmistuneiden asuntojen vuokratason selvittämiseksi. ${ }^{21}$ Loka- ja marraskuussa 1947 suoritettiin uusi tiedustelu, jossa selvitettiin sekä ennen vuotta 1941 että vuonna 1947 rakennettujen huoneistojen vuokrat. ${ }^{22}$ Tuorein tutkimus on lokakuulta 1950 . Sen aineisto on niinikään jaettu kahteen osaan. Ennen vuotta 1940 valmistuneet huoneistot tutkittiin omana ryhmänään edustavaa menetelmää käyttäen, kun taas vuosina 1940 - 1950 rakennettuja tai perusteellisesti korjattuja taloja koskeva tiedustelu sisälsi niiden kaikki enintään neljä huonetta käsittävät asunnot. ${ }^{23}$ 
Asumiskustannusten yleistä kehitystä valaisee myös eliinkustannusindeksi, jota sosiaalinen tutkimustoimisto on laskenut vuodesta 1921 alkaen ja jota julkaistaan kuukausittain $\mathrm{mm}$. Sosiaalisessa Aikakauskirjassa. Varsinaisen asunnonvuokraindeksin ohella lasketaan lämmön ja valon kustannuksille oma alaindeksinsä.

Kuntien asuntotilasto. Perusteellista selontekoa kunnanviranomaisten yrityksistä asuntotilaston alalla ei tässä voida esittää. Niihin on kuitenkin syytä kiinnittää huomiota. Esimerkkejä voidaan ottaa varsinkin $\mathrm{He}$ ls in g in kohdalta. Sen tilastotoimisto suoritti vuonna 1924 oman vuokratiedustelunsa säännöstelyn purkamisen aiheuttamasta vuokratason noususta, 1930-luvulla koottiin vuosittaista asuntoreservitilastoa ja vuoden 1950 yleisen vuokralaskennan yhteydessä asumistiheyttä valaisevaa aineistoa. ${ }^{24}$ Helsingin kaupungin tilastollisessa vuosikirjassa julkaistaan vuositilastoa kaupungin myymistä tonteista, rakennustoiminnan tukemisesta valtion ja kunnan varoilla sekä varsin perusteellisia tietoja asunnontuotannosta. Tuoreimmat kuukausinumerot asunnontuotannosta ilmestyvät lisäksi tilastotoimiston kuukausijulkaisussa.

\section{Yhteenveto.}

Jonkinlaisena yhteenvetona nykyisestä asuntotilastostamme voidaan lopuksi todeta, että sen »järjestelmän» muodostavat

1) tilastollisen päätoimiston joka kymmenes vuosi ( $0: 11 a$ päättyvinä vuosina) yleisen väestölaskennan yhteydessä suorittama ki inteistö- ja asuntotiedustelu,

2) sosiaalisen tutkimustoimiston ja rakennusasiain toimikunnan neljännesvuosittain kokoama tilasto asunnontuotannosta ja myönnetyistä rakennusluvista,

3) Suomen Pankin taloustieteellisen tutkimuslaitoksen kuukausittain laskema ns. Suomen Pankin rakennuskustannusindeksi,

4) Aravan ja A SO:ntilastot asunnontuotannon tukemisesta erilaisin valtionlainoin ja -avustuksin, 
5) sosiaalisen tutkimustoimiston ja sosiaaliministeriön asuntoasiaintoimiston vuosineljänneksittäin kokoama tilasto huoneenvuokrala takuntien

6) sosiaalisen tutkimustoimiston tarpeen vaatiessa suorittamat vuokralaskennat sekä

7) kuntien alueeltaan ja omaan käyttöönsä kokoamat e r ikoistilastot.

\section{Asuntotilaston kehittämisestä.}

Kysymys valtion tilastotoimen, ns. virallisen tilaston, kehittämisestä on ollut pysyvästi esillä aina siitä lähtien, kun maamme tilastollinen keskusvirasto 1860-luvulla perustettiin. Syy tähän on aivan luonnollinen. Teollistuva yhteiskuntamme on dynaamisessa muuttuvuuden tilassa; on sen vuoksi selvää, että sen huomioitsijat löytävät yhä uusia havainnoimisalueita ja että siten on myös jatkuva tarve tilastotoimen $l$ a a j e $\mathrm{n} t \mathrm{a}$ m is e e n. Tarve päästä syvemmäll e yksityiskohtiin, intensiivisempään tutkimukseen jo laadittavan tilaston piirissä aiheuttaa myös omat pulmansa. Pysyvänä keskustelun kohteena esiintyy niinikään tilastotyön käytännöllinen organisointi: miten aineiston kokoaminen, käyttely ja julkaiseminen eri tilastonaloilla olisi järjestettävä, jotta koneisto sallituin kustannuksin tuottaisi mahdollisimman hyvän tuloksen.

Virallisen tilaston kehittämistä on pohdittu lukuisissa valtionkomiteoissa. Asuntotilasto lienee kuitenkin saanut kehittyä täysin vailla tämän meillä niin käytetyn suunnitteluinstituution apua. Asiantila tuskin johtunee siitä, että asuntotilasto olisi ollut tyydyttắvässä kunnossa, vaan lähinnä sen ensisijaisen »kuluttajan», asuntopoliittisen suunnittelun, laimeudesta. Tarve asuntotilaston parantamiseen on kyllä tuotu esille monissa yhteyksissä. $\mathrm{Mm}$. jo vuonna 1904 julkaistussa Kansantaloudellisen Yhdistyksen »asuntokysymys-komitean» mietinnössä lausuttiin parhaillaan koossa olleelle tilastokomitealle toivomus, että myös kyseinen tilastonala otettaisiin esille. ${ }^{25}$ Senaatin lakkauttaessa komitean 
vuonna 1915 asuntotilasto, kuten esim. väestötilastokin, oli kuitenkin edelleen käsittelemättä.

Tätä nykyä vaaditaan joka taholla asuntokysymyksen tehokasta hoitamista. Tehtävä edellyttää tietysti huolellista tutkimusta ja perinpohjaista tilastoa. Parhaillaan on vireillä myös tilastotoimen kehittämisen yleissuunnittelu, mihin tehtävään on asetettu valtionkomitea tilastollisen päätoimiston ylijohtajan, prof. Valter Lindbergin johdolla. Ajankohta pyrkimyksille asuntotilaston parantamiseksi ja uudelleen järjestelemiseksi tuntuu näin ollen varsin otolliselta.

Kysymystä asuntotilaston kehittämisestä voidaan tässä yhteydessä käsitellä vain päällisin puolin pariin tilastonhaaraan rajoittuen. Seuraavassa esitettävät näkökohdat koskevatkin vain asuntolaskentaa ja asunnontuotantotilastoa.

Asuntolaskenta. Hallituksen esityksessä eduskunnalle laiksi säännöllisen, yleisen väestölaskennan toimittamisesta (HE 102/1937) sisältyy kaikki asuntolaskentaa koskeva toteamukseen, että »asuntotilaston laatimiseksi on yleinen väestölaskenta niinikään tarpeen». Esikuvana pidettiin aikaisempia kaupunkien todellisia väestölaskentoja. Niiden yhteydessähän oli suoritettu myös asuntolaskenta nähtävästi lähinnä niitä tietojen kombinoimisen ja kustannussäästöjen kannalta huomattavia etuja tavoitellen, jotka väestön ja asuntokannan tutkiminen samanaikaisesti ja samaa organisaatiota käyttäen tuo mukanaan. Tällöin ei kuitenkaan otettu ehkä riittävästi huomioon sitä kvantiteettieroa, mikä on vain muutamaan kaupunkiin rajoittuvan ja koko maan käsittävän laskennan aineistojen välillä. Laskennasta huolehtivan viranomaisen työskentelykapasiteetti on monestakin syystä rajoitettu. Liian suuresta aineistosta voi seurauksena olla vain työn viivästyminen ja tulosten käyttökelpoisuuden väheneminen.

Ruotsin vuonna 1945 toimitetun väestölaskennan yhteydessä suoritettiin myös ensimmäinen koko maan käsittävä asuntolaskenta, joka oli tarkoitettu pohjaksi sodanjälkeiselle »uuden asuntopolitiikan» suunnittelulle. Vaikka eräitä erikoisselvityksiä saa- 
tiinkin jo lähivuosina laskennan jälkeen, lopullinen selonteko viivästyi niin, että se ilmestyi vasta vuonna $1952 .{ }^{26}$ Eräänä syynä tähän on mainittu laskennan suorittaminen samanaikaisesti väestölaskennan kanssa. Sen vuoksi on ehdotettu, että tiedustelut toimitettaisiin eri ajankohtina, jolloin voitaisiin käyttää samaa henkilökuntaa, koneistoa ja huonetilaa. ${ }^{27}$

Vastaavanlaisia ajatuksia tuo mieleen myös Suomen nykyinen järjestely. Ilmeisti on, että asuntolaskennan tiedot ovat jo nyt - vuodenvaihteessa 1953/54 tulee sen suorituksesta kuluneeksi kolme vuotta - hyvää vauhtia vanhentumassa puhumattakaan siitä viivytyksestä, minkä asuntotietojen eteenpäinvieminen on aiheuttanut itse väestötietojen valmistumiselle. Toisaalta asuntolaskennan yhteiskunnallinen merkitys on niin suuri, että sen asema jonkinlaisena väestölaskennan »lapsipuolena» ei ole puolustettavissa. Sen vuoksi on syytä pohtia toimenpiteitä, jotka takaisivat tulosten tuoreuden niiden monipuolisuuden silti joutumatta kärsimään.

Kysymykseen voitaneen tässä tuskin syvemmälti paneutua. Ellei ole mahdollisuuksia nykyisen laskentaorganisaation työkyvyn lisäämiseen niin, että tehtävä voitaisiin viedä läpi parissa kolmessa vuodessa, șilloin lienee ryhdyttävä uudelleenjärjestelyyn. Kuten Ruotsissa on esitetty, erään mahdollisuuden tarjoaa asuntolaskennan irroittaminen väestölaskennasta ja sen suorittaminen esim. jokaisena 5:llä päättyvänä vuonna. Toinen mahdollisuus olisi säilyttää nykyinen järjestely, mutta supistaa laskennassa koottavien tietojen piiri mahdollisimman vähiin. Tällainen asuntokannan ja asuntotalouksien »inventaario» tarjoaisi sen jälkeen hyvän pohjan varsinaisille asuntopolitiikkaa ohjaaville erikoistutkimuksille, jotka voitaisiin jättää sopivasti sosiaalisen tutkimustoimiston tehtäväksi. Mikäli väestölaskennassa asunnoista laaditut hollerith-kortit varustetaan riittävillä identifioimistiedoilla, voidaan otantamenetelmää käyttäen suoritettavissa intensiiviselvityksissä tutkittavat asunnot (asuntotaloudet) poimia niistä koneellisesti. Tämäntapaiseen järjestelyyn siirtyminen vaatii luonnollisesti ehdottomat takeet siitä, että erikoistutkimukset tul- 
laan suorittamaan. Siitä taas tuskin on toiveita, niin kauan kuin asuntopolitiikkamme hallinto on nykyisellä kannallaan.

Niin laaja kuin vuoden 1950 asuntolaskennassa tutkittujen kysymysten piiri olikin, monet asuntopolitiikalle tärkeät seikat jäivät valaisua vaille. Laskennan tuloksia jonkinlaisin »sesamaukene»-tunnelmin odottavien asuntopoliitikkojen joukossa lienee tähän tuskin kiinnitetty huomiota. Sekä valtion asuntopolitiikan hahmottelu että asuntorakennustoiminnan paikallinen suunnittelu edellyttävät väestön asunnontarpeen ja vuokranmaksukyvyn arviointia. Tehtävään syvemmälti paneutumatta ${ }^{28}$ todettakoon, että siinä tarvitaan välttämättä tietoja $\mathrm{mm}$. sellaisista viime asuntolaskennassa - työmäärän kohtuuden rajoissa pitämiseksi — tutkimatta jätetyistä seikoista kuin tuloista ja vuokrista sekä asuntojen kunnosta. Myöskään asuntoprognoosin laatimisessa tarpeellisia talouskuntafrekvenssejä ${ }^{29}$ ei tiettävästi tulla laskemaan. Sikäli kuin asuntopoliittiseen suunnitteluun siihen tapaan kuin esim. Ruotsissa vielä päästään, mainitut puutteet tulevat varmasti esille. Asiantila on tällöin ehkä korjattavissa erikoistutkimuksin, jotka — kuten edellä viitattiin — voitaneen suorittaa esim. sosiaalisessa tutkimustoimistossa.

Asunnontuotantotilaston tähdellisyys ja sen uudistamisen tarve eivät liene kiistettävissä. Asuntopolitiikassa se on välttämätön tarkkailtaessa tuotannon riittävyyttä ja sen rakennetta esim. ahtaasti asumisen poistamisen kannalta. Tuotantoja työllisyyspolitiikan palveluksessa - investointitoiminnan ohjauksessa, kansantulolaskelmissa jne. - se on niinikään tärkeä.

Tätä nykyä asunnontuotantotilastoa kootaan sekä sosiaalisessa tutkimustoimistossa että rakennusasiain toimikunnassa. Edellinen kiinnittää huomionsa lähinnä asunnontuotannon sosiaalisiin puoliin, ja sen aineisto perustuu kunnallisten rakennusviranomaisten vapaaehtoisiin ilmoituksiin. Jälkimmäisessä taas ovat tärkeimpänä tilastoinnin kohteena erilaisten uudisrakennusten, siis muidenkin kuin asuinrakennusten, lukumäärä ja kuutiotilavuus. Aineisto kootaan vuoden 1953 loppuun saakka voimassa olevien, ns. ta- 
loudellisen valtalain perusteella annettujen valtioneuvoston sekä kulkulaitosten ja yleisten töiden ministeriön päätösten (As.kok. 1952, 3 ja 4) nojalla. Asunnontuotantotilaston kehittämisen kannalta onkin tällä hetkellä tähdellisintä sen vakinaistaminen ja keskittäminen yhteen virastoon. Erään mahdollisuuden tarjoaa tilaston sisällyttäminen tietojen antamisesta eräitä yleisiä, virallisia tilastoja varten koskevan lain (As.kok. 1940, 588) piiriin. Tällöin tulisi myös harkittavaksi kysymys tämän tilaston siirtämisestä sosiaalisesta tutkimustoimistosta tilastolliseen päätoimistoon. Toimenpidettä tuntuisi puoltavan se seikka, että sosiaalisen tutkimustoimiston päätehtävän muodostavat sosiaaliset erikoistutkimukset - kuten sen nimestäkin on pääteltävissä - eikä jatkuva tilastotyö. ${ }^{30}$

Lienee täysin aiheellinen vaatimus, että asunnontuotantotilasto olisi saatava maaseudulta yhtä yksityiskohtaisena kuin väestökeskuksista. Millaisen esteen muodostaa se seikka, etteivät rakennusviranomaiset ole maaseudulla velvolliset suorittamaan lopputarkastusta, on tietysiti vielä selvitettävä. Kuitenkin se, että rakennusasiain toimikunta pystyy hankkimaan tietoja valmistuneista asunnoista, osoittanee mahdollisuuksia täydellisemmän tilaston kokoamiseen olevan. Asunnontuotantotilaston sisältöön lopuksi kajotaksemme on syytä mainita joitakin puutteita tähänastisesta tilastosta. Sellaisena on pidettävä esim. sitä, että tiedot saneeraustoiminnasta ovat rajoittuneet mainintaan purettujen huoneiden, ei siis asuntojen, luvusta. Asuntokannan kokoonpanon muuttuminen vuodesta toiseen ei siten ole ollut seurattavissa. Edelleen olisi suotavaa, että tuotetut asunnot ryhmiteltäisiin ei vain huoneluvun vaan myös »keittiötyypin» mukaan ja että myös pinta-alatietoja kerättäisiin. Tiettävästi eräissä suhteissa, sikäli kuin kysymyksessä on sosiaalisen tutkimustoimiston kakoama väestökeskusten tilasto, onkin parannuksia odotettavisša.

$\mathrm{P}$ ä ätökseksi tälle asuntotilaston kehittämistä koskevalle lyhyelle esitykselle on vielä syytä tähdentää sitä, että kysymys olisi koko laajuudessaan saatava pohdittavaksi ja edelleen kehitettäväksi asiantuntijaforumilla. Perusteltua lienee odottaa aloi- 
tetta uudistussuunnitelmien parissa parhaillaan työskentelevien tilastoviranomaisten taholta. Luonnollista on, että asunto-olojemme kohentamisesta vastuussa olevien asuntoviranomaisten, tilaston ensisijaisten tarvitsijoiden, on niinikään kannettava oma painava kortensa tämän yhteisen keon rakentamiseen.

\section{Lähdeviitteitä.}

1 Tulokset on julkaistu Suomen virallisen tilaston (SVT) sarjassa VI (väestötilastoa) numeroissa 3 (1870), 8 ja 11 (1880), 24 (1890), 39 (1900), $50: 1-8$ ja $51: 1-2$ (1910), $54: 1-11$ (1920) sekä $72: 1-13$ (1930).

2 Asuntolaskenta huhtikuun 25 p:nä 1919. SVT XXXII (sosiaalisia erikoistutkimuksia): 2. Helsinki 1921.

3 Kaupunkien asunto-olot vuonna 1938. SVT XXXII: 19. Helsinki 1940.

4 Tehdastyöväen asunto-olot. Toimeenpannun tiedustelun päätuloksia. Sosiaalinen Aikakauskirja (=SA) 1926, $3-5$ ja 8. - Ylöstalo, Liisa, Ylioppilaiden asunto-olot syyslukukaudella 1949. SA 1950, 7-8.

${ }^{5} \mathrm{Ks}$. T(udeer), M(aija), Suomen asuntotilasto. Iso tietosanakirja 1, palsta 902. Helsinki 1931. Tulokset ovat ilmestyneet seuraavissa julkaisuissa: Sucksdorff, Vilh., Arbetarebefolkningens i Helsingfors bostadsförhallanden. Redogörelse för arbetarebostadsundersökningen âr 1900. Helsinki 1904. (Ilmestynyt myös suomennoksena.). - Ekholm, $K$., Bostadsförhällandena för de mindre bemedlade 1 Vasa år 1900. Vaasa 1904. - Gadd, Magnus, Sammanställning af arbetarbostadsundersökningen i Wiborg år 1901. Viipurin terveydenhoitolautakunnan vuosikertomus 1903. Viipuri 1904. - Borg, G., Oulun työväen asumusoloista. Oulun terveydenhoitolautakunnan vuosikertomus 1902. Oulu 1903. - Snellman, G. $R$., Tutkimus vähempivaraisten asunto-oloista vuonna 1905 Turun kaupungissa sekä viereisissä Kaarinan ja Maarian pitäjän osissa. Turku 1906. - Hällström, A. J., Tutkimus Heinolan kaupungin asunto-oloista. Työtilastollinen Aikakauslehti 1911, 3. - Backman, W., Bostadsförhảllandena i Jakobstad år 1906. Pietarsaari 1907. - Rosenberg, Sigurd, Tutkimus asuntooloista vuonna 1907 Kuopion kaupungissa sekä kaupungille kuuluvilla Männistỏn, Niiralan ja Haapaniemen alueilla. Kuopio 1908. - Manner, Viktor, Asunto-olosuhteet Hämeenlinnan kaupungissa v. 19c8. Hämeenlinna 1909. - Rikala, Kalle, Asunto-olot Jyväskylän kaupungissa 1908. Ylipainos "Keski-Suomesta". Jyväskylä 1910. - Snellman, G. R., Tutkimus vähävaraisten asunto-oloista vuonna 1909 Tampereen kaupungissa sekä viereisissä Pirkkalan ja Messukylän pitäjäin osissa. Tampere 1909 .

- Modeen, G., Asunto-olot Kotkassa syksyllä vuonna 1935. Kotkan kaupungin sosiaalilautakunnan julkaisuja. Kotka 1936. - Sama, Asuntoolot Warkaudessa. Warkauden asunto- ja rakennuspäivillä $19-20$ pnä syyskuuta 1936 pidetyt esitelmät. Warkauden asuntoreformiyhdistyksen julkaisuja n:o 1. Varkaus TY36.

Waris, Heikki, Työläisyhteiskunnan syntyminen Helsingin Pitkänsillan pohjoispuolelle I. Helsinki 1932, - Nieminen, Armas, Tietoja Helsingin suurista ja keskisuurista perheistä sekä nilden oloista vuonna 1943. Tilastollinen selvitys. Väestöliiton vuosikirja I. Porvoo-Helsinki 1946. 
8 Gebhard, Hannes, Asunto-olot. Tilattoman väestön alakomitea. Tilastollinen tutkimus yhteiskunta-taloudellisista oloista Suomen maalaiskunnissa v. 1901. II. Helsinki 1910. Sama aineisto käyteltiin vielä erikseen maanviljelystyöväestön osalta. Ks. Gebhard, Hannes, Työväenperheitten asunto- ja maataloudellisia oloja. Tilattoman väestön alakomitea. Tilastollinen tutkimus yhteiskuntataloudellisista oloista Suomen maalaiskunnissa v. 1901. V. Helsinki 1916.

9 Tutkimus Suomen maataloustyöväen oloista palkkausvuonna $1919-20$. SVT XXXII: 3. Helsinki 1923. - Maataloustyöväen asunto-olot. Ennakkotietoja toimitetun tutkimuksen tuloksista. SA 1928, 12.

10 Maaseudun asuntokomitean mietintö n:o 1. Komiteanmietintö 1937, 6 . Felsinki. Ss. $12-23$.

11 Maseudun asunto-olot vuonna 1937. SVT XXXII: 16. Helsinki 1938.

12 Maaseudun asunto-olojen parantamiskomitean mietintö. Komiteanmietintö 1951, 9. Helsinki. Ss. $31-46$.

13 Savonen, Severi, Tilastotietoja Suomen maalaiskuntien asunto-oloista. Duodecim 1938, 9. - Kinnunen, Erkki J., Palstaviljelijäperheiden asunto-olot. SA 1937, 7. - Mäki, Antti, Maatalouden rakennusoloista Suomessa v. 1938. Metsätieteellisen tutkimuslaitoksen julkaisuja 37:5. Helsinki 1949. - Nieminen, Armas, Kuopion läänin perhelisäperheistä já niiden asunto- ym. oloista. Vertaileva tilastollinen selvitys. Väestöliiton vuosikirja II. Helsinki 1948.

14 Harmaja, Leo, Tilastotieteen oppikirja. Helsinki 1939. S. 240.

is Laki säännöllisen, yleisen väestölaskennan toimittamisesta $8.4 . \quad 1938$ (As.kok. 1938, 154); asetus ko. lain soveltamisesta 16. 12. 1949 (As.kok. 1949, 769).

16 Tietoja vuoden 1950 kiinteistö- ja asuntolaskennan tuloksista sisältyy mm. seuraaviin kirjoituksiin: Tunkelo, A., Suomen rakennuskanta 31. 12. 1950. Tilastokatsauksia 1952, 7-8. - Sama, Väestölaskennan ennakkotietoja. Tilastokatsauksia 1952, 11-12. - Strömmer, Aarno, Väestökeskusten ja maaseudun asunnontarve. SA 1953, 3-4. - Helsingin osalta ks. sen tilastotoimiston julkaisemassa aikakauslehdessä "Tilastollisia kuukausitietoja Helsingistä" ilmestyneitä artikkeleita ja Helsingin kaupungin tilastollista vuosikirjaa 1953.

17 Tiedot vuosilta 1912 -25 sisältyvät prof. Eino Kuusen kirjoituksiin Asuntorakennustöiminta Suomen kaupungeissa vuosina $1912-22$, SA 1923, 8 sekä Rakennustoiminta ja asuntopulan vaiheet Suomen kaupungeissa vuosina 19121925, SA 1926, 11.

1s Maaseudun tilaston suhteen ks. Modeen, G., Maaseudun uusi rakennustuotantotilasto. Maalaiskunta 1949, 21.

19 Ks. Tamminen, Mikko, Rakennuskustannusten kehitys ja Rajaoja, Vieno, Suomen Pankin rakennuskustannusindeksi. Taloudellisia selvityksiä 1942. Suomen Pankin taloustieteellisen tutkimuslaitoksen julkaisuja. Sarja A: 1. Helsinki. - Honkanen, Lea, Suomen Pankin rakennuskustannusindeksi. Taloudellisia selvityksiä 1952. Suomen Pankin taloustieteellisen tutkimuslaitoksen julkaisuja.
Sarja A: 13. Helsinki.

so Esim. Kuusi, Eino, m.k., SA 1926, 11. - Modeen, G., Rakennustoiminta kaupungeissa vuosina 1921-28. Taloudellisen neuvottelukunnan julkaisuja 5. Helsinki 1930. - Sama, Uusien asuntojen tarve maaseudulla ja kaupungeissa. Talouselämä 1941, 7-8. - Sama, Asuntotuotanto ja asunnontarve Helsingissä. Suomen kunnallislehti 1942, 9. - Sama, Asunnontarve asutuskeskuksissa vuoden 1945 alussa. Suomen kunnallislehti 1945, 3. - Sama, Asunnontarve asutuskeskuksissa. SA 1947, 3-4. - Tamminen, Mikko, Bostadsproduktion och bostadsförsörjning i Finlands städer. Ekonomisk Tidskrift (Uppsala) 1941, 2. - Sama, Jälleenrakennustyö ja kaupunkien asuntokysymys. Kansantaloudellinen Aika- 
kauskirja 1942, 4. - Sama, Suomen kaupunkien asuntotuotannon vaihtelut ja niiden syyt itsenäisyyden aikana. Suomen Pankin taloustieteellisen tutkimuslaitoksen julkaisuja. Sarja B: 4. Helsinki 1945. - Strömmer, Aarno, m.k. - Asunnontarve Helsingissä. Tilastollisia kuukausitietoja Helsingistä 1950, 4.

- Talouskuntafrekvenssit ja asunnontarve. Tilastollisia kuukausitietoja Helsingistä 1953,3 .

21 Vuosina 1942-46 valmistuneiden asuinhuoneistojen vuokrat asutuskeskuksissa marraskuussa 1946. SA 1947, 3-4.

2 Asutuskeskuksien vuokrat loka- ja marraskuussa 1947. Tilastollinen tutkimus. I-II. SA $1948,3-4$ ja 5-6.

23 Asutuskeskuksien vuokrat lokakuussa 1950. Tilastollinen tutkimus. SA $1951,9-10$.

24 Ks. Bruun, Otto, Helsingin vuokraolot. SA 1924, 9. - Jalo, M., Helsingin kaupungin asuntoreservi vv. 1934-1937. SA 1937, 4. - Modeen, G., Asumistiheys Helsingissä syksyllä 1950. Tilastollisia kuukausitietoja Helsingistä 1951,1 .

2s Esityksiä kaupunkien asuntokysymyksen ratkaistamiseksi. Yhdistyksen asettaman komitean... mietintö. Asuntokysymys. Esitelmiä ja ehdotuksia. Julk. Kansantaloudellinen Yhdistys. Helsinki 1904.' Ss. 81-102.

26 Bostäder och hushåll enligt allmänna bostadsräkningen 1945 och därtill anslutna undersökningar. Sveriges officiella statistik. Byggnadsverksamhet och bostađisförhăllanden. Tukholma 1952.

27 $B-d, G$., Slutredovisning av 1945 års allmänna bostadsräkning. Sociala Meddelanden (Tukholma) 1952, 7.

28 Esimerkkejä asuntopoliittisista tarve- ja kustannuslaskelmista Ruotsissa tarjoavat $\mathrm{mm}$. Undersökning rörande behovet av en utvidgning av bostadsstatistiken, Statens offentliga utredningar 1933, 14 sekä Slutbetänkande avgivet av bostadssociala utredningen, Del I, Statens offentliga utredningar, 1945,63 .

29 Termin suhteen ks. esim. Bostäder och hushåll. Ss.122-126.

so Ks. esim. Sosiaalitilastokomitean mietintö. SA 1934, 12. 